\title{
Performance of selected macroinvertebrate-based biotic indices for rivers draining the Merendon Mountains region of Honduras
}

\author{
Paul O'Callaghan and Mary Kelly-Quinn \\ School of Biology and Environmental Science, Science Centre West, University College Dublin, Belfield, Dublin 4, Ireland; \\ paul.ocallaghan@ucd.ie, mary.kelly-quinn@ucd.ie
}

Received 11-VII-2012 Corrected 2-X-2012 Accepted 8-XI-2012

\begin{abstract}
Cusuco National Park, a cloud forest park situated in the Merendon Mountains region of Honduras, is home to considerable biodiversity with a very high degree of endemism. Like many other cloud forest parks in Central America, it was declared a protected area not because of its biodiversity, but mainly because of its function in protecting river water quality in the headwaters draining the park. Illegal and authorised forest clearance for agricultural activity such as coffee production and pasture for animals and diffuse inputs from settlements are expected to affect aquatic macroinvertebrate communities and the water quality of the rivers in the park. There is however very limited water quality monitoring, mainly because biological indices such as those in use in Europe and the United States have not been developed in Honduras. A research project based on macroinvertebrates was initiated in 2009 to develop a water quality index for the area. Sampling was undertaken between June and August 2009 and set out to study minimally disturbed upper catchments of reference rivers. This paper evaluates the performance of several indices. A version of the ASPT based on the BMWP calibrated for Costa Rica (BMWP(CR)) performed best.
\end{abstract}

\section{KEY WORDS}

Biomonitoring, Honduras, macroinvertebrates, neotropics, upland stream, water quality

\section{RESUMEN}

El Parque Nacional de Cusuco es un Parque ocupado en su mayor parte por un bosque de niebla que se localiza en la región de las montañas Merendon en Honduras y que alberga una considerable biodiversidad con un alto grado de endemismos. No obstante, este Parque Nacional, como muchos otros parques de bosque de niebla en Centro América, fue declarado Área protegida no por su biodiversidad, sino principalmente por su función en la protección de la calidad de las aguas fluviales de las cabeceras de las cuencas de drenaje del parque, al ser la fuente de agua potable para varias áreas urbanas de gran tamaño entre las que se incluye San Pedro Sula. Se espera que clareos de bosque, tanto ilegales como autorizados, para actividades agrícolas como la producción de café y pasto para los animales, y el aporte difuso desde los asentamientos, afecten a las comunidades de macroinvertebrados acuáticos y a la calidad del agua de los ríos del parque. Sin embargo, hay una monitorización muy limitada de la calidad del agua, debido principalmente a que los índicos biológicos como aquellos que se usan en Europa y en los Estados Unidos entre otros, no han sido desarrollados en Honduras. En 2009 se inició un proyecto de investigación con el fin de desarrollar un índice de calidad de agua basado en macroinvertebrados. Muestreo se llevó a cabo entre junio y agosto de 2009, y en ella se propuso muestrear captaciones superiores mínimamente alteradas de ríos de referencia. Este artículo evalúa el resultado (rendimiento) de una gama de índices de calidad de agua existentes, basados en macroinvertebrados bajo condiciones de referencia. Estos emplazamientos están en bosques primarios con poca o ninguna evidencia de influencias antropogénicas actuales o históricas. Dada la falta de influencias antropogénicas en estos lugares, se espera que varios índices devuelvan resultados que indiquen un alto estatus. Los factores que causan la desviación de los resultados esperados son examinados. Una versión del ASPT basado en el BMWP calibrado para Costa Rica (BMWP(CR)) es la que da mejores resultados.

PALABRAS CLAVE

Biomonitoreo, Honduras, macroinvertebrados, neotrópico, corriente de la montaña, calidad del agua. 
There is a limited body of research on freshwater systems in tropical regions. Efforts to build on existing knowledge are hampered by political and financial considerations as well as issues of access to papers in various disparate journals and so called 'grey literature' (Jackson \& Sweeney, 1995a; Springer, 1998). Furthermore, a lack of taxonomic expertise and local reference collections in the neotropics, an obligatory first step for community ecological studies, presents certain difficulties (Springer, 1998). However, neotropical streams are receiving increasing attention from researchers due to their considerable ecological and economic importance (Covich, 1988).

Most of our current models for stream nutrient dynamics, decomposition, and regulation of community structure have been derived from extensive and detailed research on lotic systems in temperate zones (Wantzen, Ramírez \& Winemiller, 2006). To what extent these apply to neotropical systems is unclear. In terms of anthropogenic pressures temperate streams tend most commonly to be affected by channel modification and diffuse pollution (Wantzen et al., 2006) among others. Diffuse pollution from agriculture has also been documented in the neotropics (Castillo et al., 2006) and like most areas neotropical streams are often affected by airborne contaminants (Standley \& Sweeney, 1995). However, Central American streams are more commonly affected by point sources such as municipal sewage and localised sediment inputs usually associated with land-use change (Biggs, Dunne \& Martinelli, 2004; Mol \& Ouboter, 2004; Baptista et al., 2007).

A basic requirement for the management of pollution pressure is the accurate assessment and monitoring of water quality, something that can be conducted using direct physico-chemical measurements or indirect measurements (measuring the effect of a pressure on an organism, group of organisms or some aspect of these) (Rosenberg \& Resh 1993). Chemical monitoring can miss or underestimate even recent pollution events unless continuous, and therefore expensive, monitoring is employed (Rosenberg \& Resh, 1993) and should ideally only be used in support of ecological assessment. Therefore, the use of biotic indices based on macroinvertebrate assemblages is now the main approach in the United States (USEPA, 1972; Hilsenhoff, 1988; Rosenberg \& Resh, 1996; Barbour et al., 1999) and Europe (Armitage et al., 1983; Alba-Tercedor \& Sanchez-Ortega, 1988; WFD, 2000; AQEM-consortium, 2002) to assess water quality. However, water quality monitoring in the neotropics is still largely limited to chemical/physical parameters despite the fact that biological methods offer more practical advantages as they can overcome the logistical difficulties of traditional chemicalphysical surveys and are advantageous from an economic point of view (Fenoglio, Badino \& Bona, 2002, Fenoglio,
2005). In Central America and in particular in countries such as Honduras and Costa Rica there is large demand for rapid bioassessment methods and metrics (Fenoglio et al., 2002). In this respect the use of macroinvertebrates seems advantageous as taxonomic and ecological information on these groups is better known in the tropics than other biota such as algae (Jackson \& Sweeney, 1995b).

Before embarking on the development of new biotic indices for a region it is useful to undertake an assessment of the performance of existing systems and in what respect they are applicable to the new biogeographic region. Although most of the macroinvertebrate families used in biotic indices from the more northern regions are also found in the tropics, they may not necessarily occupy the same niche or have the same functional role as in temperate regions, and furthermore, they may not be similarly sensitive to water quality deterioration. The present study tested how well biotic indices from other biogeographic regions measured water quality in upland rivers/streams in a mountainous region of Honduras where there is little or no anthropogenic inputs from land-use activities. It is common practice to perform initial testing of indices in unpolluted conditions (Armitage et al., 1983) and this approach can be particularly useful when working in poorly studied areas where natural environmental gradients may confound interpretation of anthropogenic effects. We compared water quality classifications for each index based on two factors, firstly how many sites were indicated to be of high quality and secondly how many local invertebrate taxa were taken into account by the given index.

\section{METHODOLOGY}

\section{Site Selection}

The data were collected from El Parque Nacional Cusuco in the Merendon Mountains region of northern Honduras ( $15^{\circ} 29^{\prime} 41,028^{\prime \prime} \mathrm{N}$ and $\left.88^{\circ} 12^{\prime} 48,4554^{\prime \prime} \mathrm{W}\right)$ from June to August 2009. Fifteen minimally impacted sites were chosen across seven catchments using a GIS model with sites being chosen on the basis of hydromorphological characteristics. These typing characteristics included catchment size, geology and slope (Fig. 1).

\section{Sampling protocol}

Three replicate, 2-minute macroinvertebrate kick samples were taken with a standard pond net $(1000 \mu \mathrm{m}$ mesh) at each site using a multi-habitat sampling procedure with time in each habitat spent proportional to the frequency of its occurrence at the site (Wright, 1995; Wright, 


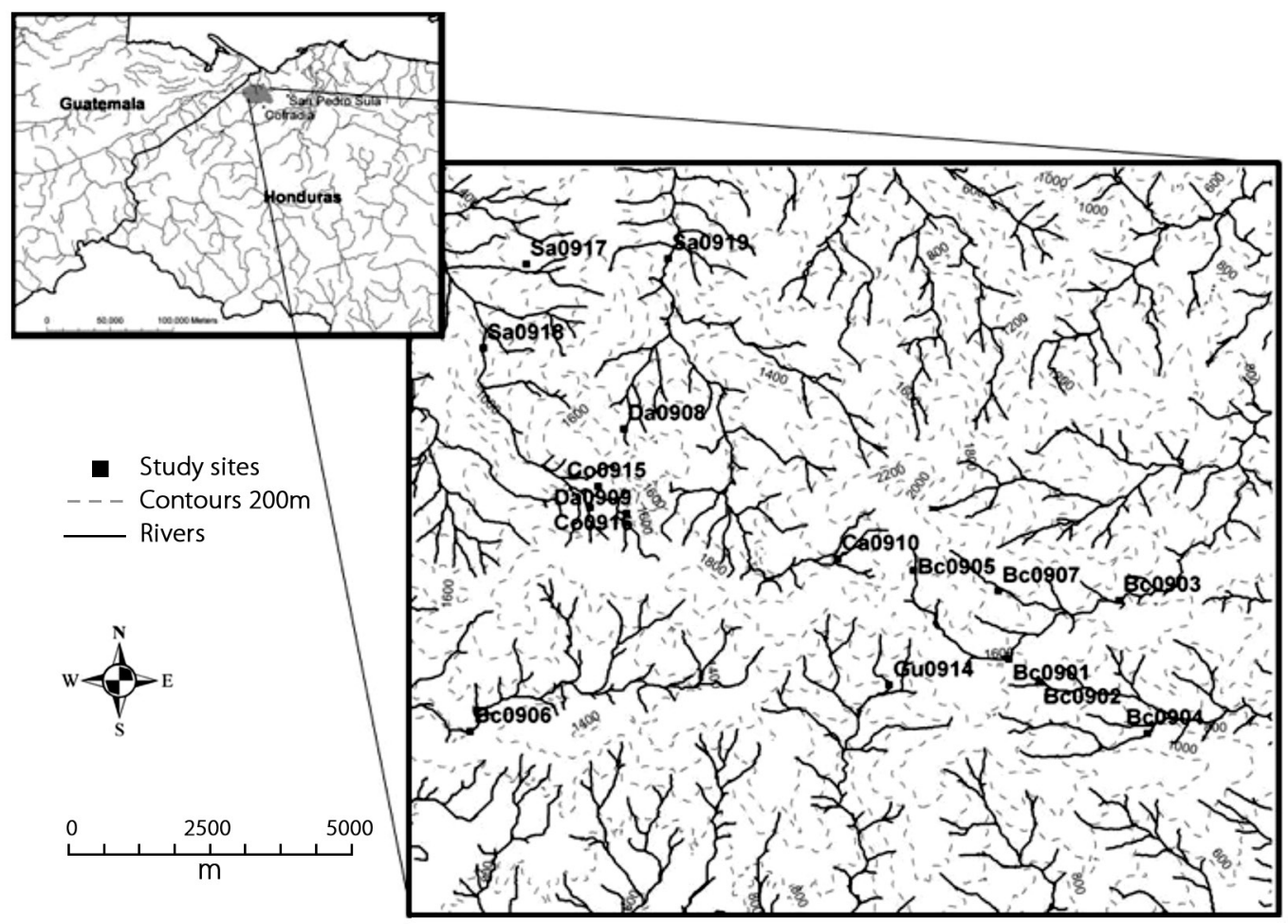

FIG. 1. Map showing location of el Parque Nacional Cusuco in Honduras and sampling site locations.

Furse \& Moss, 1998). Samples were returned to the nearest camp to be live sorted and the contained macroinvertebrates were preserved in 70\% ethanol. Individuals smaller than $1000 \mu \mathrm{m}$ may have been lost but this is a standard methodology often used in routine bioassessment (Wallace, Grubaugh \& Whiles, 1996; Whiles et al., 2000; Dickens \& Graham, 2002; Callanan, Baars \& Kelly-Quinn, 2008). Specimens were returned to the laboratory in University College Dublin and identified to family level, this being the taxonomic level used in most bioassessment metrics.

\section{Biotic Indices Applied}

Indices calculated included the Biological Monitoring Working Party (BMWP) (Armitage et al., 1983) and its associated Average Score Per Taxon (ASPT), as well as the version calibrated for Costa Rica (Ministerio del Ambiente y Energía, 2006) and the Spanish version calibrated for the Iberian peninsula (IBMWP and IASPT) (Alba-Tercedor \& Sanchez-Ortega, 1988). The South African Scoring System (SASS) (Chutter, 1994; Dickens \& Graham, 2002) and its associated ASPT were calculated as well as Hilsenhoff Family Level Biotic Index (FBI) (Hilsenhoff, 1988). The BMWP was developed in Britain across a wide range of river types including smaller upland streams and has been shown to be reliable across a wide altitudinal gradient (Armitage et al., 1983; Zamora-Muñoz et al., 1995), the system assigns each family a score between one and ten, based on its sensitivity to organic pollutants. Pollution-sensitive families have high scores and pollution-tolerant ones low scores. No adjustment is made to allow for relative abundances of the various families (Armitage et al., 1983; Walley \& Hawkes, 1997). The ASPT is simply the BMWP score divided by the number of scoring taxa (Armitage et al., 1983). The SASS was first developed by Chutter and is now on its $5^{\text {th }}$ iteration (Chutter, 1994). It is based on the BMWP system with each family assigned a score the sum of these giving the SASS. Furthermore, the number of scoring families (NTa$\mathrm{xa}$ ) and an ASPT are calculated. It is a combination of the SASS and the ASPT scores which indicates the quality of the river. The Hilsenhoff or FBI (Family-level Biotic Index) is calculated by multiplying the abundance of each indicator family by its tolerance value, summing the products and dividing by the total number of macroinvertebrates in the sample. This index does not include families from the Hemiptera or Coleoptera (except Elmidae and Dryopidae) 
(Hilsenhoff, 1988). The index cut-off levels used for high, good and moderate water quality for the various biotic indices are given in Table 1.

One-way ANOVA was performed to compare index values between sites. As all sites are considered to be minimally impacted scores calculated by the various indices are not expected to differ significantly between sites.

ASPT(CR) was also calculated for a further six sites within the park which are characterised by high levels of iron either in solution or as precipitate. These high iron levels occur naturally and are thought to be the result of exposed geology resulting from landslides. The ASPT(CR) scores for these sites were compared to six other sites within the same altitudinal range using one-way ANOVA.

\section{RESULTS}

A total of 60 families were recorded across all fifteen sites with an average of 25 families per site. Representatives from most invertebrate groups were recorded, however a single amphipod family represented the Crustacea and both Mollusca and Arachnida were absent. A list of those taxa found during the study including those not used in the calculation of the various metrics is presented in Table 2. The original BMWP had the greatest number of un-scored taxa at 31 with the Costa Rican BMWP having the lowest number un-scored at nine. This included a minimum of three trichopteran families (BMWP(CR) and IBMWP indices) and a maximum of eight trichopteran

TABLE 1

Values used to assign various index scores to water quality classes

\begin{tabular}{lccccc}
\hline & $\begin{array}{c}\text { IBMWP/ } \\
\text { BMWP(CR) }\end{array}$ & ASPT & $\begin{array}{c}\text { Hilsenhoff } \\
\text { FBI }\end{array}$ & \multicolumn{2}{c}{ SASS } \\
\hline High & $>100$ & $>6$ & $0-3,75$ & $>100$ & $>6$ \\
Good & $61-100$ & $4-5$ & $3,76-5,5$ & $<100$ & $>6$ \\
Moderate & $36-60$ & $3-4$ & $5,51-6,5$ & $50-100$ & $<6$ \\
Poor & $16-35$ & $2--3$ & $6,51-8,5$ & $<50$ & variable \\
Bad & $<15$ & $1-2$ & $8,5-10$ & &
\end{tabular}

TABLE 2

List of Taxa used in the calculation of each biotic index.

\begin{tabular}{|c|c|c|c|c|c|}
\hline Taxon & BMWP & IBMWP & BMWP(CR) & Hilsenhoff & SASS \\
\hline \multicolumn{6}{|l|}{ Hydropsychidae } \\
\hline \multicolumn{6}{|l|}{ Leptoceridae } \\
\hline Hydrobiosidae & $x$ & $x$ & & $x$ & $x$ \\
\hline Philopotamidae & $\mathrm{X}$ & & & & \\
\hline \multicolumn{6}{|l|}{ Lepidostomatidae } \\
\hline Calamoceratidae & $x$ & $x$ & & $x$ & \\
\hline Ecnomidae & $x$ & & & $x$ & \\
\hline Brachycentridae & $x$ & & $X$ & & $x$ \\
\hline Glossosomatidae & $x$ & & & & \\
\hline Rhyacophilidae & & & $x$ & & $x$ \\
\hline Polycentropodidae & & & & & \\
\hline
\end{tabular}


TABLE 2 (Continued)

List of Taxa used in the calculation of each biotic index.

\begin{tabular}{|c|c|c|c|c|c|}
\hline Taxon & BMWP & IBMWP & $\mathrm{BMWP}(\mathrm{CR})$ & Hilsenhoff & SASS \\
\hline Apataniidae & $x$ & $x$ & $x$ & $\mathrm{X}$ & $x$ \\
\hline Odontoceridae & & & & & $x$ \\
\hline Limnephilidae & & & & & $x$ \\
\hline Hydroptilidae & $x$ & & & & \\
\hline Notonectidae & & & & $X$ & \\
\hline Veliidae & $x$ & & $x$ & $\mathrm{X}$ & \\
\hline Naucoridae & & & & $x$ & \\
\hline Gerridae & & & $x$ & $x$ & \\
\hline Belostomatidae & $x$ & $x$ & & $x$ & \\
\hline Corixidae & & & & $x$ & \\
\hline \multicolumn{6}{|l|}{ Elmidae } \\
\hline Amphizoidae & $x$ & $x$ & $x$ & $x$ & $x$ \\
\hline Psephenidae & $x$ & $x$ & & $x$ & \\
\hline \multicolumn{6}{|l|}{ Dryopidae } \\
\hline Hydrophilidae & & & & $x$ & \\
\hline Lampyridae & $x$ & $x$ & & $x$ & $x$ \\
\hline Scirtidae & $x$ & $x$ & & $x$ & $x$ \\
\hline Dytiscidae & & & & $x$ & \\
\hline Gyrinidae & & & & $\mathrm{X}$ & \\
\hline Hydraenidae & $x$ & $x$ & & $x$ & \\
\hline Tricorythidae & $x$ & $x$ & & & \\
\hline \multicolumn{6}{|l|}{ Leptophlebiidae } \\
\hline \multicolumn{6}{|l|}{ Heptageniidae } \\
\hline \multicolumn{6}{|l|}{ Baetidae } \\
\hline \multicolumn{6}{|l|}{ Perlidae } \\
\hline \multicolumn{6}{|l|}{ Chironomidae } \\
\hline Simuliidae & $x$ & $x$ & & & \\
\hline Ceratopogonidae & $x$ & & & & \\
\hline \multicolumn{6}{|l|}{ Tipulidae } \\
\hline Blephariceridae & $x$ & & & & \\
\hline Ephydridae & $x$ & & & & \\
\hline Athericidae & $x$ & & & & \\
\hline Empididae & $x$ & & & & \\
\hline Dolichopodidae & $x$ & & & & $x$ \\
\hline Gomphidae & & & & & $x$ \\
\hline Coenagrionidae & $x$ & & & & \\
\hline Libellulidae & & & & & $x$ \\
\hline Calopterygidae & $x$ & & & & \\
\hline
\end{tabular}


TABLE 2 (Continued)

List of Taxa used in the calculation of each biotic index.

\begin{tabular}{lccccc}
\hline \multicolumn{1}{c}{ Taxon } & BMWP & IBMWP & BMWP(CR) & Hilsenhoff & SASS \\
\hline Platystictidae & $\mathrm{X}$ & $\mathrm{X}$ & & $\mathrm{X}$ & $\mathrm{X}$ \\
Lestidae & & & & & $\mathrm{X}$ \\
Aeshnidae & & & & & $\mathrm{X}$ \\
Cordulegastridae & & & & & \\
Corduliidae & $\mathrm{X}$ & $\mathrm{X}$ & & & $\mathrm{X}$ \\
Corydalidae & $\mathrm{X}$ & $\mathrm{X}$ & $\mathrm{X}$ & $\mathrm{X}$ & $\mathrm{X}$ \\
Neargyractis & $\mathrm{X}$ & $\mathrm{X}$ & $\mathrm{X}$ & $\mathrm{X}$ & $\mathrm{X}$ \\
Crambidae & $\mathrm{X}$ & $\mathrm{X}$ & $\mathrm{X}$ & $\mathrm{X}$ & $\mathrm{X}$ \\
Petrophila & $\mathrm{X}$ & $\mathrm{X}$ & & & \\
Amphipoda & 31 & 17 & 9 & 22 & 19 \\
Total & & & & & \\
X denotes that the taxon was not included. & & & & \\
& & & &
\end{tabular}

families in the case of British BMWP. However the majority of these were encountered infrequently and in low numbers. Table 3 lists those taxa which occurred in more than five sites and had on average at least one individual per site but were not scored by the various biotic indices. This includes only seven families with none of the applied indices having more than four non-scoring families.

\section{BMWP and ASPT}

The BMWP scores fell between 50,3 and 121 and the ASPT values between 6,45 and 7,44 . All ASPT values exceeded 6,0 (Table 4), a value generally considered to represent high quality (Chutter, 1994; Chapman, 1996; Callanan et al., 2008). The IBMWP allocated $33,3 \%$ (5 sites) of sites to high quality, $46,6 \%$ (7 sites) to good and the remaining $20 \%$ (3 sites) to moderate quality (Table 4) (range 51,6 to 127) while the IASPT assigned $100 \%$ (15 sites) of sites to high status (range 6,27 to 7,30) (Table 4). Finally the Costa Rican version of BMWP assigned $46,6 \%$ (7 sites) of sites to high status, $46,6 \%$ (7 sites) of sites to good status and the remaining site $(6,6 \%)$ to moderate status (range 61 to 141,6 ) while the ASPT(CR) classified 100\% (15 sites) of sites as high status (range 6,11 to 6,77 ).

\section{Hilsenhoff (FBI) Index}

The Hilsenhoff index categorises scores in a seven point scale ranging from excellent (less than 3,75 ) to very poor $(7,26-10)$. Four of these classes have been combined into two for the purposes of comparison, Hilsenhoff's very good and good classes have been combined and are here referred to as good and in addition Hilsenhoff's fair and fairly poor combined and referred to as moderate, ranges used can be seen in Table 1. Here only sites scoring below 3,75 (lower scores indicate higher quality in the Hilsenhoff index) were considered to be of high quality as above this value the index allows for slight organic impact. Scores achieved by the sites fell between 2,82 and 3,87 . The Hilsenhoff index indicated that $80 \%$ (12 sites) of sites were of high quality with the remaining three sites classified as good (Table 4).

\section{SASS (South African Scoring System)}

Sites are assigned to quality classes according to Chutter (1994) based on both the SASS score and ASPT. For example a site was considered of high quality if SASS was above 100 and ASPT above 6, if one of these fell below these levels it was considered good quality and if both were below these values the site was considered moderate (Table 1). Of the 15 sites 13,3\% (2 sites) were of high quality and the remaining sites were classified as good quality (Table 4).

\section{Statistical Analysis}

One-way ANOVAs were carried out to compare calculated index values between sites. All indices based on the BMWP (BMWP, BMWP(CR), IBMWP and SASS) showed significant differences between sites $\left(F_{14,30}=4,352, p=0,00\right.$, $F_{14,30}=5,116, p=0,00, F_{14,30}=4,285, p=0,00, F_{14,30}=7,013$, 
TABLE 3

Non-scoring taxa occurring in more than 5 sites at an average of $>1$ individual per site.

\begin{tabular}{|c|c|c|c|c|c|}
\hline Taxon name & BMWP & IBMWP & BMWP (CR) & Hilsenhoff & SASS \\
\hline Odontoceridae & & & & & $x$ \\
\hline Naucoridae & & & & $x$ & \\
\hline Psephanidae & $x$ & $x$ & & $x$ & \\
\hline Gomphidae & & & & & $x$ \\
\hline Coenagrionidae & $x$ & & & & \\
\hline Platystictidae & $x$ & $x$ & & $x$ & $x$ \\
\hline Corydalidae & $x$ & $x$ & & & $x$ \\
\hline Total & 4 & 3 & 0 & 3 & 4 \\
\hline
\end{tabular}

TABLE 4

Percentage of sites assigned to high, good or moderate water quality by the selected biotic indices.

\begin{tabular}{lccc}
\hline \multicolumn{1}{c}{ Index } & High & Good & Moderate \\
\hline ASPT & 100 & 0 & 0 \\
BMWP(CR) & 46,6 & 46,6 & 6,6 \\
ASPT(CR) & 100 & 0 & 0 \\
IBMWP & 33,3 & 46,6 & 20 \\
IASPT & 100 & 0 & 0 \\
SASS/ASPT & 13,3 & 86,6 & 0 \\
Hilsenhoff (FBI) & 80 & 20 & 0
\end{tabular}

$p=0,00$, respectively). These differences lay between several relatively low scoring sites (including sites 2, 9, 19 and in particular site 17 which was assigned particularly low scores in all BMWP based indices) and 3 sites which were generally assigned very high scores (1, 6 and 16).

In contrast, while 3 of the sites failed to be rated as high quality according to the Hilsenhoff (FBI) index the scores did not vary significantly between sites $\left(F_{14,30}=1,496, p=\right.$ 0,172 ). No significant differences were found between values calculated using the various ASPT indices except for ASPT(SASS) $\left(F_{14,30}=4,230, p=0,00\right)$. The significant difference can be attributed to one site (site 2 ) which while scoring significantly lower than several other sites still lay over the threshold for high quality according to the SASS index.

When naturally iron enriched sites were compared with six unenriched sites in a similar altitudinal range ASPT(CR) scores for the six iron enriched sites were significantly lower than the unenriched sites $\left(F_{1,34}=24,168, p=0,00\right)$. All six sites were classified as at least good quality by the ASPT(CR) index with one site reaching high quality.

\section{DISCUSSION}

This study assessed the performance of various water quality indices applied to headwater streams in Cusuco National Park, Honduras. While almost no stream in Central America will be completely devoid of anthropogenic influence most notably airborne contamination, those selected were in catchments with no or minimal human land-use disturbance. Therefore, all sites used in the study were considered to represent reference condition. Generally the selected indices performed quite well. Ideally an index would score all sites as high quality and leave no widely occurring taxa unscored. If several taxa are not included in the calculation of the index it may limit the general applicability of the index across rivers of varying typology. In general, the ASPT indices performed much better than the BMWP indices with scores tending to be higher. ASPT scores also tended to be much more stable with ANOVA analysis showing no significant differences between sites with the exception of the SASS version.

In the SASS system quality classes are not assigned separately for SASS(BMWP) and ASPT but are based on both. For example the criteria for high quality status are that sites must reach an SASS(BMWP) score of $\geq 100$ and an ASPT of $\geq 6$. In the present study while the ASPT(SASS) scores did vary significantly between sites the minimum score was 6,07 , therefore the variation in quality class between 
sites was due to the BMWP component of the SASS. The Costa Rican ASPT system was quite effective, this is not surprising as this was calibrated in Central America and had the lowest number of non-scoring families at nine. Three of these were tricopteran families (Apataniidae, Brachycentridae and Rhyacophilidae) taxa which generally tend to be sensitive to various pressures (Bernard, Neil \& Rowe, 1990; Vuori, 1996; Maret et al., 2003; Menetrey et al., 2008). However, none of these taxa left scoreless by the Costa Rican BMWP was either widespread or present in large numbers and so would not be considered important as indicators. The IASPT also performed relatively well, again this metric left relatively few families scoreless (17) which probably contributed to its good performance, of these three occurred widely (Table 3 ) including a beetle (Psephenidae) and a damselfly (Platystictidae) both of which are considered relatively sensitive by the other indices. Fenoglio (2005) found that the IBMWP index rated all sites as excellent quality, however in that study some family scores were corrected using those from the Hilsenhoff index. These corrections were not performed in the present study. ASPT has been shown to be relatively robust in other studies (Lorenz et al., 2004, Sandin \& Hering, 2004; Callanan et al., 2008). This would seem to be confirmed by the present study with all ASPT systems performing well, even when the corresponding BMWP was not so robust.

The Hilsenhoff family level biotic index assigned 80\% (12) of sites to high status and the remainder to good status. While this metric left 22 of the families identified without scores only three of these were widespread, two of which (Psephenidae and Platystictidae) would generally be considered sensitive with the third (Naucoridae) being generally considered relatively tolerant. Those sites failing to reach high status scored very close to the good/high boundary. The fact that this metric takes account of abundance probably explains why these sites failed to reach high status. These are upland sites and while they tend to have high scoring families they are not necessarily present in large numbers and the 100 individuals required for the Hilsenhoff standard methodology were not always obtained.

While most of the metrics considered performed reasonably well, overall the Costa Rican ASPT tended to exhibit least variation between sites and showed the most potential for water quality assessment in this region due to its high rating of most sites and that fact that none of the taxa occurring in more than 5 sites was unscored. However, one needs to consider whether adjustment of scores for local conditions in Cucuso, as undertaken by Fenoglio (2005) in Guinope, would produce a more robust tool for the upland streams in the Merendon Mountains region. This can be best achieved by examination of the macroinvertebrate communities across a gradient of pollution, a task which is currently underway by the authors through experimentation as impacted sites cannot be found/accessed within the altitudinal range of the reference sites.

When applied to naturally iron enriched sites in all but one case the ASPT(CR) failed to assign these sites to high status. Of these sites most contained large quantities of iron precipitate, this precipitate tended to deposit on the bed and under rocks creating a relatively simple habitat similar to a heavily silted river. This resulted in low invertebrate abundance. This is a clear indication that these sites, in particular those with high levels of precipitate, must be treated as a separate typology and more appropriate quality class boundaries applied.

In developing countries there is a clear need for rapid and inexpensive tools to assess water quality (Ongley, 1998; Pesce \& Wunderlin, 2000). The use of already existing biotic indices would hold obvious advantages as they could be employed quickly and without the costs associated with the development of a novel index. The results of the present study are encouraging and suggest that with minor amendments a range of existing indices, particularly those based on ASPT, can be quickly adapted to areas such as Honduras.

\section{ACKNOWLEDGEMENTS}

We would like to thank the people of Cusuco National Park for their cooperation and guidance on the numerous excursions in the forest. We also thank the staff and volunteers of Operation Wallacea for supporting the project.

\section{REFERENCES}

Alba-Tercedor, J. \& Sanchez-Ortega, A. (1988). Un metodo rapido y simple para evaluar la calidad biológica de las agues corrientes basado en el de Hallawell (1987). Limnetica 4, 51-56.

AQEM-consortium (2002). Manual for the application of the AQEM system. A comprehensive method to assess European stream using benthic macroinvertebrates, developed for the purpose of the Water Framework Directive. Version 1.0, February 2002.

Armitage, P.D., Moss, D., Wright, J.F. \& Furse, M.T. (1983). The performance of a new biological water quality score system based on macroinvertebrates over a wide range of unpolluted running-water sites. Water Research 17(3), 333.

Baptista, D., Buss, D., Egler, M., Giovanelli, A., Silveira, M. \& Nessimian, J. (2007). A multimetric index based on benthic macroinvertebrates for evaluation of Atlantic Forest streams at Rio de Janeiro State, Brazil. Hydrobiologia 575(1), 83. 
Barbour, M.T., Gerritsen, J., Snyder, B.D. \& Stribling, J.B. (1999). Rapid bioassessment protocols for use in streams and wadeable rivers: periphyton, benthic macroinvertebrates and fish. EPA 841-B-99-002. - U.S. Environmental Protection Agency; Office of Water: Washington, D.C., USA

Bernard, D., Neil, W. \& Rowe, L. (1990). Impact of mild experimental acidification on short term invertebrate drift in a sensitive British Columbia stream. Hydrobiologia 203(1), 63-72.

Biggs, T.W., Dunne, T. \& Martinelli, L.A. (2004). Natural Controls and Human Impacts on Stream Nutrient Concentrations in a Deforested Region of the Brazilian Amazon Basin. Biogeochemistry 68(2), 227.

Callanan, M., Baars, J.R. \& Kelly-Quinn, M. (2008). Critical influence of seasonal sampling on the ecological quality assessment of small headwater streams. Hydrobiologia 610(1), 245.

Castillo, L.E., Martínez, E., Ruepert, C., Savage, C., Gilek, M., Pinnock, M. \& Solis, E. (2006). Water quality and macroinvertebrate community response following pesticide applications in a banana plantation, Limon, Costa Rica. Science of Total Environment 367(1), 418.

Chapman, D. (1996). Water Quality Assessments - A Guide to Use of Biota, Sediments and Water in Environmental Monitoring. UNESCO/WHO/UNEP, Great Britain at the University Press: Cambridge

Chutter, F.M. (1994). The rapid biological assessment of streams and river water quality by means of macroinvertebrate communities in South Africa. - In Uys MC (ed) Classification of Rivers and Environmental Health Indicators. Water Research Commission Report No. TT 63/94, South Africa, 217-234.

Covich, A.P. (1988). Geographical and historical comparisons of neotropical streams: biotic diversity and detrital processing in highly variable habitats. Journal of the North American Benthological Society 361-386.

Dickens, C.W.S. \& Graham, P.M. (2002). The South African Scoring System (SASS) Version 5 Rapid Bioassessment Method for Rivers. African Journal of Aquatic Science 27, 1-10.

Fenoglio, S. (2005). Ecological quality and benthic invertebrates communities in the Rio Cangrejal basin. La Ceiba, Honduras. USAID-MIRA, Internal report.

Fenoglio, S., Badino, G. \& Bona, F. (2002). Benthic macroinvertebrate communities as indicators of river environment quality: an experience in Nicaragua. Revista de Biología Tropical 50(3/4), 1125-1132.

Hilsenhoff, W.L. (1988). Rapid Field Assessment of Organic Pollution with a Family-Level Biotic Index. Journal of the North American Benthological Society 7(1), 65.

Jackson, J.K. \& Sweeney, B.W. (1995a). Present status and future directions of tropical stream research. Journal of the North American Benthological Society 14(1), 5-11.

Jackson, J.K. \& Sweeney, B.W. (1995b). Research in tropical streams and rivers: introduction to a series of papers. Journal of the North American Benthological Society 2-4.
Lorenz, A., Hering, D., Feld, C. \& Rolauffs, P. (2004). A new method for assessing the impact of hydromorphological degradation on the macroinvertebrate fauna of five German stream types. Hydrobiologia 516(1), 107-127.

Maret, T.R., Cain, D.J., MacCoy, D.E. \& Short, T.M. (2003). Response of benthic invertebrate assemblages to metal exposure and bioaccumulation associated with hard-rock mining in northwestern streams, USA. Journal of the North American Benthological Society 22(4), 598-620.

Menetrey, N., Oertli, B., Sartori, M., Wagner, A. \& Lachavanne, J. (2008). Eutrophication: are mayflies (Ephemeroptera) good bioindicators for ponds? Hydrobiologia 597(1), 125-135.

Ministerio del Ambiente y Energía. (2006). Propuesta de Ley del recurso hídrico No.14.585 Reglamento para la evaluación y clasificación de la calidad de cuerpos de aguas superficiales. MINAE: Costa Rica.

Mol, J.H. \& Ouboter, P.E. (2004). Downstream effects of erosion from small-scale gold mining on the instream habitat and fish community of a small neotropical Rainforest stream. Conservation Biology 18(1), 201-214.

Ongley, E. (1998). Modernisation of water quality programmes in developing countries: issues of relevancy and cost efficiency. Water Quality International Sept/Oct, 37-42.

Pesce, S.F. \& Wunderlin, D.A. (2000). Use of water quality indices to verify the impact of Córdoba City (Argentina) on Suquía River. Water Research 34(11), 2915-2926.

Rosenberg, D.M. \& Resh, V.H. (1993). Freshwater Biomonitoring and Benthic Macroinvertebrates. Chapman and Hall: New York, USA.

Rosenberg, D.M. \& Resh, V.H. (1996). Use of aquatic insects in biomonitoring. - In: Merritt, R.W., Cummins, K.W. An introduction to the Aquatic Insects of North America, 87-96.

Sandin, L. \& Hering, D. (2004). Comparing macroinvertebrate indices to detect organic pollution across Europe: a contribution to the EC Water Framework Directive intercalibration. Hydrobiologia 516(1), 55-68.

Springer, M. (1998). Genera of Aquatic Insects from Costa Rica, deposited at the Museo de Zooiogia, Universidad de Costa Rica. Revista de Biología Tropical 46(6), 137-141.

Standley, L.J. \& Sweeney, B.W. (1995). Organochlorine pesticides in stream mayflies and terrestrial vegetation of undisturbed tropical catchments exposed to long-range atmospheric transport. Journal of the North American Benthological Society 14(1), 38.

USEPA (1972). Clean Water Act of 1972. Public Law 92-500. USA

Vuori, K.M. (1996). Acid-induced acute toxicity of aluminium to three species of filter feeding caddis larvae (Trichoptera, Arctopsychidae and Hydropsychidae). Freshwater Biology 35(1), 179-188.

Wallace, J.B., Grubaugh, J.W. \& Whiles, M.R. (1996). Biotic Indices and Stream Ecosystem Processes: Results from an Experimental Study. Journal of Applied Ecology 6(1), 140-151. 
Walley, W.J. \& Hawkes, H.A. (1997). A computer-based development of the Biological Monitoring Working Party score system incorporating abundance rating, site type and indicator value. Water Research 31(2), 201.

Wantzen, K.M., Ramírez, A. \& Winemiller, K.O. (2006). New Vistas in Neotropical Stream Ecology - Preface. Journal of the North American Benthological Society 25(1), 61-65.

W.F.D. (2000). CEC 2000. Directive of the European parliament and of the council 2000/60/EC establishing a framework for community action in the field of water policy. Official Journal of the European Communities 327/3

Whiles, M.R., Brock, B.L., Franzen, A.C. \& Dinsmore, I.I.S.C. (2000). Stream invertebrate communities, water quality, and land-use patterns in an agricultural drainage basin of northeastern Nebraska, USA. Environment Management 26(5), 563-576.

Wright, J.F. (1995). Development and use of a system for predicting the macroinvertebrate fauna in flowing waters. Australian Journal of Ecology 20(1), 181-197.

Wright, J.F., Furse, M.T. \& Moss, D. (1998). River classification using invertebrates: RIVPACS applications. Aquatic Conservation: Marine and Freshwater Ecosystems 8(4), 617-631.

Zamora-Muñoz, C., Sáinz-Cantero, C.E., Sánchez-Ortega, A. \& Alba-Tercedor, J. (1995). Are biological indices BMPW' and ASPT' and their significance regarding water quality seasonally dependent? Factors explaining their variations. Water Research 29(1), 285. 